\title{
A Global Comparison of Insider Trading Regulations
}

\author{
James H. Thompson \\ Associate Professor of Accounting \\ 2400 South $240^{\text {th }}$ Street \\ Des Moines, WA 98198 \\ 206-439-3800 x3839Ｅmail: jht@cwu.edu
}

Received: January 29, 2013 Accepted: February 15, 2013 DOI: 10.5296/ijafr.v3i1.3369

\begin{abstract}
As the business world continues to expand in global markets, trading of shares, bonds, derivatives and other instruments continues to increase. One form of trading that has received considerable interest in recent years is insider trading. Insider trading occurs when individuals with potential access to non-public information about a corporation buy or sell stock of that corporation. When the information is material and non-public, such trading is illegal. However, if the trading is done in a manner that does not take advantage of non-public information, it is often permissible. This study compares insider trading laws, penalties, and convictions in countries represented by the 14 largest securities markets throughout the world and provides data indicating that there are important differences.
\end{abstract}

Keywords: Insider trading, global markets 


\section{$\Lambda$ Macrothink}

\section{Introduction}

As the business world continues to expand in global markets, trading of shares, bonds, derivatives and other instruments continues to increase. One form of trading that has received considerable interest in recent years is insider trading. Insider trading occurs when individuals with potential access to non-public information about a corporation buy or sell stock of that corporation. When the information is material and non-public, such trading is illegal. In these cases, individuals are aware of nonpublic information gained through the performance of their duties and thereby are in breach of a fiduciary or other position of trust. However, if the trading is done in a manner that does not take advantage of non-public information, it is often permissible. This study compares insider trading laws of the largest markets throughout the world, with attention to differences in definitions, penalties, and convictions. This examination permit will identify markets, and therefore countries, that place the greatest emphasis on regulating and enforcing insider trading laws.

Regulation and enforcement of insider trading laws is important to investors for a number of reasons. First, investors are likely to be more confident in the financial statements of companies that operate in countries with strong insider trading laws if such laws are enforced consistently. In addition, investments within such countries may be viewed as less risky as the information is considered to be more reliable. Finally, as risk and the return investors require on an investment are positively correlated, investments may have a lower required rate of return.

\section{Background}

The United States has historically been the world leader in insider trading law. In 1909, the U.S. Supreme Court ruled in Strong v. Repide that because a company director could affect the value of his company's shares, keeping buyers ignorant of his expected actions while selling his own shares would be deceitful and therefore fraudulent. Although this was the first major step in the foundation for insider trading law, statutory regulation did not begin until the passage of the Securities Act of 1933.

More recently, the Martha Stewart case drew international attention to the ethics of insider trading. In 2004 she was convicted of conspiracy, obstruction of an agency proceeding, and making false statements to federal investigators and sentenced to five months in prison and an additional two years of supervised release, plus restitutions and fines totaling more than $\$ 200,000$. The loss to her reputation was enormous as well. Notoriety from this incident highlights potential loopholes within insider trading laws as well as the need for sufficient deterrents to make the violation less attractive.

As a result of the Stewart case and other similar cases, many countries may find it necessary to reevaluate their laws regarding insider trading. Some countries are strengthening their existing laws and providing for increased enforcement. Other countries, however, are only beginning to establish insider trading laws or are not enforcing laws already in place. The Economist that states "many countries do not pursue insider-trading convictions, or if they do, only impose financial penalties" (Economist.com, 2011). 


\section{Ml Macrothink}

International Journal of Accounting and Financial Reporting

\section{Methodology}

In determining the specific countries to study, major stock exchanges were ranked based on market capitalization as of December 31, 2011 (Wikipedia, 2012). Of the sixteen most active exchanges, fifteen are located in thirteen countries: the United States, Japan, the United Kingdom, France, China, Canada, India, Brazil, Australia, Germany, Switzerland, Spain, and South Korea. Another is located in Hong Kong, which was examined separately from China because its stock exchange is subject to different regulations. For the purposes of this study, Hong Kong was considered to be a "country." Thus, the study investigates insider trading regulation and enforcement for fourteen countries throughout the world. Table 1 shows the fourteen countries by size of market.

\begin{tabular}{|l|c|c|}
\hline \multicolumn{3}{|c|}{ Table 1 } \\
\hline \multicolumn{2}{|c|}{ Rank of Countries } \\
barket Capitalization \\
\hline Countries & $\begin{array}{c}\text { Market } \\
\text { Cap } \\
\text { (Trillions) }\end{array}$ & Rank \\
\hline United States & 18.682 & 1 \\
\hline China & 3.412 & 2 \\
\hline Japan & 3.325 & 3 \\
\hline United Kingdom & 3.266 & 4 \\
\hline France & 2.930 & 5 \\
\hline Hong Kong & 2.258 & 6 \\
\hline India & 1.992 & 7 \\
\hline Canada & 1.912 & 8 \\
\hline Brazil & 1.229 & 9 \\
\hline Australia & 1.198 & 10 \\
\hline Germany & 1.185 & 11 \\
\hline Switzerland & 1.090 & 12 \\
\hline Spain & 1.031 & 13 \\
\hline South Korea & 0.996 & 14 \\
\hline
\end{tabular}

Archival data were gathered for each country. Data gathered includes the definition of an insider, the year in which the first insider trading law was passed, prohibited actions, legal penalties, and convictions. The countries were then compared on these criteria.

Several imitations apply to the data gathered. Primarily, some information was unavailable for a few countries, or was not available in English. For several countries, no clear list of insider trading convictions was obtained. By reviewing articles about specific cases, convictions were identified, although the number was not determinable. Also, if no cases were identified, it was unclear if a country had no convictions or if articles mentioning those convictions were not readily available. Therefore, without definitive numbers of 
convictions, comparing enforcement levels of the different countries was difficult.

\section{Data}

\subsection{The United States}

The United States has the two largest stock exchanges (by market capitalization) in the world: New York Stock Exchange and NASDAQ. Thus, the United States ranks first in the world by market capitalization. With such a concentration of securities trading in U.S., insider trading laws are extremely important.

Statutory insider trading laws were first passed in 1933. Congress passed the Securities Act of 1933 and the Securities and Exchange Act of 1934. Both Acts were intended to increase transparency for investors while placing the obligation of due diligence on the preparers of documents containing detailed information about the security. The second Act created the Securities and Exchange Commission (SEC) to regulate the secondary trading of securities. Ultimately, the Acts bolstered investor confidence and helped to stimulate the economy.

The SEC creates the rules that govern the securities market and also enforces them along with the Department of Justice. The SEC is the most active all the world's financial regulatory institutions at prosecuting insider trading and the laws. Much of the law in the U.S. has been developed in the courts because of United States' tradition of common law (Newkirk, 1998).

The definition set forth by the SEC for what insider trading is and who can be convicted of insider trading leaves some room for interpretation and is the reason that much of insider trading law is from court decisions. Insider trading is defined as, "whenever it shall appear to the commission that any person has violated any provision of this title or the rules or regulations thereunder by purchasing or selling a security or security-based swap agreement... while in possession of material, nonpublic information..." (SEA, 1934). This implies that anyone who has access to nonpublic information and acts on it could be convicted of insider trading. In fact, the SEC has brought cases against corporate officers, directors, employees of the company, friends, business associates, family members, government employees, and other persons who took advantage of confidential information (Astarita, 2010). Notably, members of Congress are exempt from insider trading penalties.

The penalties for insider trading are a maximum of 20 years in prison and a fine of $\$ 5$ million. These fines were increased in the Sarbanes-Oxley Act of 2002 (Brody 2009). In addition, those convicted of insider trading can face civil penalty fines, which can be up to three times the profit gained or loss avoided as a result of an unlawful purchase (SCA, 1934).

Recently, there was a major case in the United States with Raj Rajaratnam, the former hedge fund manager of the Galleon Group. Convicted on 14 counts of securities fraud, he was sentenced to 11 years in prison. This was the longest term ever imposed for insider trading, and Rajaratnam faces a $\$ 92.8$ million fine, also the largest ever (Pulliam Bray, 2011). The U.S. and the SEC have taken a hard stance on insider trading. In 2009 alone, the U.S. took action in 35 cases and made criminal convictions in 31 one of them. More than one-third of 


\section{MInstitute Macrothink $_{\text {Int }}$}

International Journal of Accounting and Financial Reporting ISSN 2162-3082 2013, Vol. 3, No. 1

these cases involved at least three defendants, and nine of the cases involved profits or avoided losses of at least \$4 million (Krey, 2010).

\subsection{China}

China has two major stock exchanges: Shanghai and Shenzhen Stock Exchanges. China ranks second in the world for market capitalization.

The securities market in China is regulated by the China Securities Regulatory Commission (CSRC). China first made insider trading illegal in 1993 with the introduction of the Establishment of Securities Companies with Foreign Equity Participation Rules. They are in a unique position because their economy has grown so quickly that they have needed to play catch-up in terms of insider trading regulation. Both the Shanghai and Shenzhen stock exchanges have only been established since the early 1990s. Insider trading in China is thought to be widespread with one expert believing that about 80 percent of all securities cases are connected with insider trading (Huang, 2005).

Insiders in Chinese securities law include directors, managers, board members, shareholders, employees, staff of the CSRC, and other persons specified by the securities regulatory authority under the State Council. These insiders are forbidden from trading based off of insider knowledge and also tipping and procurement. Inside information in China is defined as, "... information that is not made public because, in the course of securities trading, it concerns the company's business or financial affairs or may have a major effect on the market price of the company's securities" (Huang, 2005). Punishment for insider trading is a maximum fine of five times the illegal proceeds from illegally purchased or sold securities. If the case is serious enough, those convicted could also face criminal charges and a maximum prison sentence of 10 years. China has begun to model its enforcement system after the successful U.S. system to attempt to better enforce insider trading regulation (Shen, 2008).

In China's short market history there have only been twelve publicly reported insider trading cases. From 2001 to 2005 the United States brought 271 enforcement actions while China only brought three. The reason is not that insider trading does not occur in China. Wu Jinglian, head of the State Development Research Council, called China's stock markets "worse than a casino" and a paradise for speculators (Shen, 2008).

\subsection{Japan}

By market capitalization, the Tokyo Stock Exchange is the third largest stock exchange in the world. This ranks Japan as third in the world by market capitalization.

In 1988, Japan passed its first insider trading law with the Financial Markets Abuse Act. The Financial Markets Abuse Act is enforced by Japan's Financial Services Agency (FSA) along with the Securities and Exchange Surveillance Committee (SESC). In April 1989, there was a very public insider trading scandal which led to stricter insider trading regulation. Japanese insider trading law is very specific and is based on the "access" doctrine. The access doctrine focuses on persons with access to the information, which includes employees, 
and prohibits trading by such insiders or trading by persons tipped by those insiders (Meany, 2010).

The Financial Markets Abuse Act carries a maximum of three years in prison and a maximum fine of JPY 3 million $(\$ 37,800$ as of $6 / 8 / 12)$ for insider trading convictions. A corporate insider in Japan is anyone who knows material information before the information becomes public and is related to the company. This definition includes directors, employees, shareholders, and government regulatory supervisors. The law does not explicitly prohibit a corporate insider from tipping, but it could constitute aiding and abetting under general criminal law if trading by the tippee would amount to a crime. Material information is defined as facts such as profit results or mergers which may have a significant influence on the investment decisions of investors. This definition is similar to the United States' definition but different from most of the world where material information is defined as information, if known to investors, would cause a material impact on the price of the security. For information to be considered public, it must be published in at least two different media sources for 12 hours (Meany, 2010).

Japan is working to strengthen its insider trading laws. In October 2009, the SESC recommended that an individual consultant working for Price Waterhouse Coopers in Japan be fined JPY 1.29 million for trading using information he had gathered through his daily work for one of his clients, Link Theory Holdings Co. The verdict rendered was that the consultant purchased shares of his client, Link Theory, based on knowledge that the client was about to be purchased (Meany, 2010).

\subsection{United Kingdom}

The London Stock Exchange is the fourth largest exchange in the world by market capitalization. This places the United Kingdom fourth in the world by market capitalization.

In the United Kingdom the Financial Services Authority (FSA) regulates securities trading. The FSA aims to ensure that the stock markets are orderly and fair. Insider trading was considered illegal in 1980, but the FSA has struggled to convict people of insider trading and lags behind the United States when it comes to enforcement. In the Financial Services and Markets Act of 2000, stricter and more specific guidelines were laid out by the FSA (FSA.gov, 2008).

In the United Kingdom an insider is any person who has inside information. An insider may be a part of management, an employee, a shareholder. Insider trading may occur as a result of criminal activities or a friend tipping them off. Inside information is defined as, "information that is not generally available and that a reasonable investor would use to help them make investment decisions. It is also information that, if generally available, would be likely to significantly affect the price of an investment" (FSA.gov, 2008). In other words, the information must be material.

The punishment for insider trading or any kind of market abuse is a maximum of seven years imprisonment or an unlimited fine. On top of these penalties, a wider range of civil penalties could be imposed. 


\section{Mll Macrothink}

International Journal of Accounting and Financial Reporting ISSN 2162-3082 2013, Vol. 3, No. 1

The FSA is planning to institute tougher insider trade penalties. Margaret Cole, interim head of the FSA's business conduct unit, has asked for the maximum prison sentence for insider trading to be increased to 10 years. She believes that stronger penalties would help to discourage insider trading in the first place and help the United Kingdom do a better job of enforcing insider trading (Masters, 2011).

\subsection{France}

The Euronext Stock Exchange is the fifth largest by market capitalization. To illustrate insider trading laws for Euronext Stock Exchange countries, France was selected. France is one of the major countries involved with Euronext. Other countries that the operate within the Euronext Stock Exchange are the United States, the United Kingdom, the Netherlands, Portugal, Ireland, and Belgium. The Euronext countries first passed insider trading laws between 1930 and 1980.

Insider trading was initially recognized as a problem in France during the late 1960s, and the first law was passed in 1970. The current law, the French Monetary and Financial Code, was passed in 2000 and amended in 2005, and defines insider trading and establishes penalties. However, the Banking and Financial Regulation Act that was passed on October 22, 2010, significantly increased the maximum penalties. The Autorité des Marchés Financiers, or AMF, oversees Paris Euronext and all other financial markets in France.

Article L465-1 of the Monetary and Financial Code defines an insider as an executive of a company, a person who, through the practice of their profession or the performance of their functions, obtains privileged information, or a third party who receives such privileged information. The Code prohibits insiders from carrying out or facilitating transactions before the public has knowledge of the information that is privileged. Furthermore, the Code prohibits communicating the privileged information to third parties "outside the framework of his profession or his functions" (Monetary and Financial Code, 2005). While the 2005 Code listed a maximum penalty of two years' imprisonment and a fine of $€ 1,500,000$, which could be increased to up to ten times the amount of profit, the 2010 Banking and Financial Regulation Act increased the maximum penalty to $€ 100$ million (Gide, 2011).

\subsection{Hong Kong}

The major exchange of Hong Kong is the Hong Kong Stock Exchange. Hong Kong ranks sixth in the world by market capitalization.

In 1989, Hong Kong enacted the Securities and Futures Commission Ordinance which created the Securities and Futures Commission (SFC) to supervise and regulate the securities market. In 1991, the Ordinance was amended to include insider trading regulations. Despite its strict laws and regulations, Hong Kong made its first criminal conviction in 2008.

According to the Securities and Futures Commission Ordinance, an insider "is a connected person with relevant information" (Securities \& Future Ordinance, 2002). Like other countries, the Ordinance defines an insider in broad terms. In addition, the Ordinance defines 


\section{MInstitute Macrothink $_{\text {Int }}$}

International Journal of Accounting and Financial Reporting ISSN 2162-3082

insider trading as "dealing in relation to a public corporation when a person connected with the corporation and having information which he knows is relevant information in relation to the corporation deals or counsels in the public securities of the corporation or their derivatives" (Securities \& Future Ordinance, 2002). Penalties for insider trading are a maximum fine of HK\$23 million and/or up to 10 years in prison (Mao, Bloomberg, 2011).

In 2003, insider trading became a crime, and in 2008 Hong Kong made its first criminal conviction of insider trading. The case involved Ma Hon-Yeung, a former investment banker of BNP Paribas Peregrine Capital Ltd. and four others who allegedly used insider information to buy shares of the Egana Jewellery \& Pearls Ltd. before the company publicly announced in July 2006 a plan to privatize the company (Sasanow, 2008). The organization made progress in 2009 when it secured nine criminal convictions; of the nine cases there were five cases that involved prison time. It also froze over HK $\$ 100$ million in assets of suspected insider cases (Steward, 2009).

\subsection{India}

India has two major stock exchanges: Bombay Stock Exchange and National Security Exchange of India. India ranks seventh in the world by market capitalization.

In 1992, India enacted the Securities and Exchange Board of India (SEBI) to regulate the market and enforce insider trading laws. However, the SEBI took over 17 years to realize the term "insider trading" did not literally mean "insiders within the company." This was a humble incident for Indian regulators. In 2010, SEBI completed 10 insider trading cases, but there was not a criminal conviction. India has not made a criminal conviction of insider trading to date (Mehta, 2011).

Currently, SEBI defines an insider as "any persons including corporate officers, directors, employees, friends, business associates, family members, persons and other tippers with inside information that can influence stock prices" (SEBI Act No. 15, 1992). SEBI also states that "no insider shall-either on his own behalf or on behalf of any other person to deal, communicate, and counsel a person to directly or indirectly sell securities with unpublished price sensitive information." Violators of insider trading in India are punishable up 3 times the amount of profits and/or 1 to 10 years in prison. There are several unique factors about insider trading laws in India. First, family members of a director or officer that own securities in the director or officer's company must disclose to the public when there is a change in securities holding (SEBI, 2008). Secondly, India implements a compounding offense and consent process, which allows violators of insider trading to pay fines and fees instead of going through the criminal proceeding and potentially serving prison time (SEBI, 2007). As a result of the compounding offense and consent process, India has not made a criminal conviction to date.

\subsection{Canada}

Toronto Stock Exchange is the major exchange of Canada. Canada ranks eighth in the world by market capitalization. 


\section{Mll Macrothink}

International Journal of Accounting and Financial Reporting ISSN 2162-3082

Canadian regulatory structure is unique because the country does not have a federal organization to regulate the securities market. The regulation duties are delegated to individual provinces, and each province creates and manages its own regulations. The provincial and territorial regulators work together to coordinate and harmonize regulation of Canadian securities markets through the Canadian Securities Administrators (CSA). Investors can raise their complaints with the CSA, but the enforcement activity is conducted locally where the investors, respondents, and complainants are located (Securites-adminstrators.ca, 2009). However, the Government of Canada is currently launching an initiative to create a single federal organization. The transition is still in its infancy stage (Csto-btcvm.ca, 2011).

Insider trading laws in Canada have changed significantly since Canada passed its first insider trading laws in 1966. Currently, the two of the most important insider trading laws in Canada are the Criminal Act and the Canada Business Corporation Act. The Canada Business Corporation Act defines an insider as "the corporation, an affiliate of the corporation, director, officer, persons who owns, directly or indirectly shares of the corporation, an employee, a person receiving material confidential information, a prescribed person" (LAWS-LOIS.Justice, 2011). Also, "illegal insider trading involves buying or selling a security of an issuer while possessing undisclosed material information about the issuer, and includes related violations such as 'tipping' information and trading by the person 'tipped."' Under the Criminal Act, violators of insider trading laws may face up to C\$5 million in fines and/or a maximum of 10 years in prison (CANLII.org, 2011).

In 2010, Canada concluded 13 insider trading cases and enforced fines and fees of C\$1.9 million (CSA, 2011). In the same year, the country prosecuted its second ever criminal conviction of insider trading. The Canadian court sentenced Mr. Grmovsek to 39 months for illegal insider trading in Canada and the United States. Grmovsek and his co-defendant, Gil Cornblum, started an illegal insider trading scheme in which Cornblum sought and obtained material, non-public information about pending corporate transactions that he passed to Grmovsek, who then executed trades in the securities of the corporations involved in the corporate transactions for a profit that they shared (Greenwood, 2010).

\subsection{Brazil}

Brazil has two major stock exchanges: San Paulo Stock Exchange and The Brazilian Mercantile and Futures Exchange. Brazil ranks ninth in the world by market capitalization.

In 1976, Brazil implemented the Corporation Act that created the Brazil Securities Commission (CVM) to regulate the stock market exchange, ensure fair trading practice, and protect investors from market manipulation. The Act was passed in 1976, but the country did not make its first criminal conviction relating to insider trading until 2010. In 2010,Sadia's former director of investor relations, Luiz Gonzaga Murat Jr., was fined in $\mathrm{R} \$ 349,000$ and sentenced to one year and nine months in prison, while former board-member Romano Ancelmo Fontana Filho was fined in $\mathrm{R} \$ 375,000$ and one year and five months in prison (Rodrigues, 2011). 
Under a current version of the Corporation Act, insiders include "corporation officers, directors, or controlling shareholders, but virtually anyone may be subject to the prohibition, as long as he/she possesses information and, knowing it has not yet been made public." The Act also states that insider trading occurs when "anyone with any information not yet revealed to the public, which he obtained directly or indirectly and which may significantly affect the quotation of securities, and that they may not make use of such information to obtain any advantages for himself or for third parties by purchasing or selling securities" (Carvalhosa et al, 1982). Violators of illegal insider trading may face a maximum fine of $\mathrm{R} \$ 29.5$ million and/or five years in prison (Luna et al, 2009).

Insider trading is currently widespread in Brazil and will likely continue until the government steps up its enforcement activities. The government's inability to enforce insider trading laws is a reflection of Brazil's culture and lack of business ethics training. As one author states, "the struggle against insider trading in Brazil will probably be coincident with the struggle against corruption. Since corruption in this country seems to be largely a cultural phenomenon, it could take a very long time to see significant changes. Corruption is inversely related to education. Therefore, the battle against corruption and insider trading will depend on whether the country is able to put forward sound and sustainable public educational policies in the future" (De Medeiros, 2009).

\subsection{Australia}

The major exchange of Australia is the Australian Securities Exchange. Australia ranks tenth in the world by market capitalization.

Historically, insider trading in Australia was not prohibited until the Securities Industry Acts were enacted in 1970. In 1989, the Standing Committee on Legal and Constitutional Affairs met to examine and inquire into the adequacy of existing legislative controls over mergers, takeovers and monopolization (aph.gov.au, 1989). Their findings and recommendations were summarized in the Griffiths Report. Several reforms were enacted following the report in 1991, including the elimination of a distinction between primary and secondary insiders.

Currently, the Australian Securities and Investment Commission (ASIC) oversees and regulates activity on the Australian Securities Exchange, as required by the Corporations Act of 2001. According to the Corporations Act, an insider is "a person who possesses inside information." Inside information is defined as "information that is not generally available" which "if the information were generally available, a reasonable person would expect it to have a material effect on the price or value of particular Division 3 financial products" (Sect. 1042A, 2001). The Act further states that "the insider must not (whether as principal or agent): apply for, acquire, or dispose of, relevant Division 3 financial products, or enter into an agreement to apply for, acquire, or dispose of, relevant Division 3 financial products; or procure another person to apply for, acquire, or dispose of, relevant Division 3 financial products, or enter into an agreement to apply for, acquire, or dispose of, relevant Division 3 financial products" (Sect. 1043A, 2001). Penalties for insider trading are a maximum fine of AUD $\$ 495,000$ or three times the total value of benefits received, or 10 years imprisonment. 
A recent case of note was that of Oswyn Indra de Silva, a resident of Kuala Lumpur, who was sentenced to two years and six months in prison for "front-running" trades of his employer. By purchasing the same stocks that his employer, Macquarie Bank, planned to purchase, then selling the stocks after his employer purchased them, he was able to turn a profit of approximately AUD\$1.41 million. Because de Silva elected to plead guilty early in the process, his sentence was reduced.

\subsection{Germany}

The major exchange of Germany is the Deutsche Borse. Germany ranks eleventh in the world by market capitalization.

In Germany, no regulations regarding insider trading existed before 1970. From 1970 to 1994, only voluntary guidelines existed. In 1994, the Securities Trading Act, or Wertpapierhandelsgesetz, was passed, prohibiting trading on private information by corporate insiders. However, the Securities Trading Act did not restrict other trading, and it lacked a requirement to report trades. In 2002, the Act was amended and included a reporting requirement.

Under current law, insiders are prohibited "from taking advantage of their knowledge of inside information to acquire or dispose of insider securities for their own account or for the account or on behalf of a third party, disclosing or making available inside information to a third party without authority to do, and recommending a third party, on the basis of their knowledge of inside information, to acquire or dispose of insider securities" (Securities Trading Act, 1998). Additionally, "A third party who has knowledge of inside information shall be prohibited from taking advantage of that knowledge to acquire or dispose of insider securities for his own account or for the account or on behalf of others." German law does make a distinction between primary insiders, defined as persons with a direct contact to insider facts, and secondary insiders, who simply possess inside information. All trades by corporate insiders must be reported to the company and to the BundesanstaltfürFinanzdienstleistungsaufsicht (BaFin), the German equivalent of the SEC.

\subsection{Switzerland}

The major exchange of Switzerland is the SIX Swiss Exchange. Switzerland ranks twelfth in the world by market capitalization.

Switzerland passed its first insider trading law in 1988. The law was revised, and in 2007, the Federal Act on the Swiss Financial Market Supervisory Authority was passed, merging the Federal Office of Private Insurance, the Swiss Federal Banking Commission, and the Anti-Money Laundering Control Authority into the Swiss Financial Markets Authority (FINMA), the agency responsible for all Swiss financial regulation.

Swiss law distinguishes between primary and secondary insiders. Primary insiders are defined as "any person who is a member of the board of directors or the management board, an auditor or an agent of a company limited by shares or a company controlling or dependent on such a company, or as a member of a public authority or a public official, or an auxiliary 


\section{Mll Macrothink}

International Journal of Accounting and Financial Reporting ISSN 2162-3082 2013, Vol. 3, No. 1

to any of the aforementioned persons" while a secondary insider is "any person who receives such information directly or indirectly from any of the persons mentioned in Section 1 and obtains a financial advantage for himself or another through the exploitation of such information" (Swiss Criminal Code). Prohibited conduct includes "obtaining a financial advantage for himself or another by using or making known to a third party confidential information, the knowledge of which will have a substantial and foreseeable influence on the price of listed or pre-listed shares, other securities or corresponding book entry securities, or options on any of the aforementioned securities traded on a Swiss stock exchange." The maximum penalty for engaging in insider trading is a fine or up to three years in jail for primary insiders, and a fine or up to one year in jail for secondary insiders.

\subsection{Spain}

The major exchange of Spain is the BME Spanish Exchanges. Spain ranks thirteenth in the world by market capitalization.

Regulation of insider trading was virtually non-existent until the mid-eighties. In 1986, Spain joined the European Economic Community, subjecting the country to EC Directive 85/592 which required modification of existing regulations. As a result, the Spanish Securities Market Act was passed in 1988, significantly reforming financial markets.

Spanish law defines an insider simply as any person who possesses inside information. Inside information is defined as "information of a precise nature, relating to one or more issuers of securities or to one or more securities, which has not been public and if it had made public could or would have had a significant effect on the price of the security or securities in question" (Welch, 2005). Prohibited conducted is listed simply as "Preparing or carrying out any sort of operation in relation to transferable securities or financial instruments to which the inside information relates or any other securities, financial instruments or contract of any sort, regardless of whether it is admitted to trading on a secondary market or not, if the inside information relates to the underlying transferable securities or financial instruments."

\subsection{South Korea}

Korea Exchange is the major stock market of South Korea. South Korea ranks fourteenth in the world by market capitalization.

The Securities and Exchange Act of South Korea was originally passed in 1962, but the Act has been amended a total of 18 times, the latest amendment occurring in 2002 ("unpan1.un.org, 2003). This act defines an insider as, "Officers, employees, or major stockholders."

In 1989, there were accusations of insider trading among the five major South Korean securities firms. After an investigation was launched, the market went from 1,007 points down to 800 points (Savada and Shaw, 1990).

More recently, in early 2012, an insider trading scandal involved many key government officials related to stock manipulation and the development of a diamond mine (Lee, 2012). Upon discovery of the incident, the South Korean energy ministry called for strict discipline 
for insider trading.

The maximum prison sentence in South Korea for violating insider trading laws is 20 years (FMA International, 2008). Financial penalties can be enforced up to 3 times the gain made or loss avoided.

\section{Findings}

The study finds that all fourteen countries have laws against illegal insider trading. One significant difference in these countries is the year in which the passage of insider trading laws first occurred (See Table 2). For example, the United States first passed insider trading laws in 1934 whereas India first passed its laws in 1992. Thus, even though securities markets have been around since the late 1900s, the fight against insider trading is a relatively recent global phenomenon. Figure 1 presents the number of countries that passed insider trading laws by decade. Notably, four of the fourteen countries passed insider trading laws in the 1990s.

\begin{tabular}{|c|c|c|c|c|c|c|}
\hline \multicolumn{7}{|c|}{ Table 2} \\
\hline \multicolumn{7}{|c|}{ Laws \& Regulations by Each Country } \\
\hline Countries & Enforcement Body & Specific Laws & Year & $\begin{array}{l}\text { Maximum } \\
\text { Fines \& Fees }\end{array}$ & $\begin{array}{l}\text { Maximum } \\
\text { Prison } \\
\text { time }\end{array}$ & $\begin{array}{l}\text { Key points } \\
\text { of difference } \\
\text { with insider } \\
\text { trading laws }\end{array}$ \\
\hline $\begin{array}{l}\text { United } \\
\text { States }\end{array}$ & Securities and Exchange Commission & $\begin{array}{l}\text { Securities Exchange Act of } \\
1934\end{array}$ & 1934 & $\begin{array}{l}\text { Civil: Greater } \\
\text { of } \$ 1 \text { million } \\
\text { or } 3 \text { times } \\
\text { amount of } \\
\text { profit Criminal } \\
\text {-maximum } \$ 5 \\
\text { million }\end{array}$ & 20 years & $\begin{array}{l}\text { One of the } \\
\text { first countries } \\
\text { to institute } \\
\text { insider } \\
\text { trading laws } \\
\text { and is the } \\
\text { most } \\
\text { developed }\end{array}$ \\
\hline China & $\begin{array}{lll}\text { China Securities Regulatory } & \text { Commission } \\
(\mathrm{CSRC}) & & \end{array}$ & $\begin{array}{l}\text { Establishment of } \\
\text { Securities Companies with } \\
\text { Foreign Equity } \\
\text { Participation Rules }\end{array}$ & 1993 & $\begin{array}{l}5 \text { times illegal } \\
\text { proceeds }\end{array}$ & 10 years & $\begin{array}{l}\text { Catching up } \\
\text { to the rest of } \\
\text { the world } \\
\text { with their } \\
\text { regulation }\end{array}$ \\
\hline Japan & Financial Services Agency & $\begin{array}{l}\text { Financial Markets Abuse } \\
\text { Act }\end{array}$ & 1988 & JPY 3 million & 3 years & $\begin{array}{l}\text { Employees } \\
\text { can only } \\
\text { trade on } \\
\text { information } \\
\text { reported by at } \\
\text { least two } \\
\text { media } \\
\text { sources }\end{array}$ \\
\hline
\end{tabular}




\begin{tabular}{|c|c|c|c|c|c|c|}
\hline $\begin{array}{l}\text { United } \\
\text { Kingdom }\end{array}$ & Financial Services Authority & Criminal Justice Act & 1980 & Unlimited & 7 years & \\
\hline France & AMF or Autorité des Marchés Financiers & $\begin{array}{l}\text { Monetary and Financial } \\
\text { Code of 2000, Banking } \\
\text { and Financial Regulation } \\
\text { Act of } 2010\end{array}$ & 1970 & $\begin{array}{l}\text { EUY } \quad 100 \\
\text { million }\end{array}$ & 2 years & $\begin{array}{l}\text { Lesser } \\
\text { penalties for } \\
\text { secondary } \\
\text { insiders }\end{array}$ \\
\hline Hong Kong & Securities Futures Commissions & Securities Ordinance 1991 & 1991 & HK\$26 million & 10 years & $\begin{array}{l}\text { Criminal } \\
\text { prosecution } \\
\text { started in } \\
2008\end{array}$ \\
\hline India & Securities \& Exchange Board of India & SEBI Act 1992 & 1992 & $\begin{array}{l}3 \text { times amount } \\
\text { the profit }\end{array}$ & 10 years & $\begin{array}{l}\text { Can opt to } \\
\text { pay fines } \\
\text { instead of } \\
\text { serving jail } \\
\text { time }\end{array}$ \\
\hline Canada & Different governing body for different provinces & $\begin{array}{l}\text { Securities Act \& Criminal } \\
\text { Act }\end{array}$ & 1966 & C\$5 million & 10 years & $\begin{array}{l}\text { There is no } \\
\text { one } \\
\text { governing } \\
\text { body }\end{array}$ \\
\hline Brazil & Brazilian Security Commission & Brazilian Legislation Act & 1976 & $\mathrm{R} \$ 19$ million & 5 years & $\begin{array}{l}\text { Insider } \\
\text { trading } \\
\text { directly } \\
\text { reflect the } \\
\text { country's } \\
\text { culture }\end{array}$ \\
\hline Australia & $\begin{array}{l}\text { Australian Securities and Investment } \\
\text { Commission }\end{array}$ & Corporations Act & 1970 & $\begin{array}{l}\text { Greater } \\
\text { AUD } \$ 495,000 \\
\text { or } 3 \text { times } \\
\text { amount } \quad \text { of } \\
\text { profit }\end{array}$ & 10 years & $\begin{array}{l}\text { Not } \\
\text { prohibited } \\
\text { until } 1970\end{array}$ \\
\hline Germany & $\begin{array}{l}\text { BaFin } \\
\text { (BundesanstaltfürFinanz-dienstleistung-saufsicht) }\end{array}$ & $\begin{array}{l}\text { Securities Trading Act } \\
\text { (Wertpapier-handelsgesetz) }\end{array}$ & 1994 & $?$ & $?$ & $\begin{array}{l}\text { No regulation } \\
\text { until 1970, } \\
\text { then only } \\
\text { voluntary } \\
\text { reporting } \\
\text { guidelines } \\
\text { until } 1994\end{array}$ \\
\hline Switzerland & Swiss Financial Market Authority (FINMA) & Swiss Criminal Code & 1988 & $?$ & 3 years & $\begin{array}{l}\text { Only } 1 \text { year } \\
\text { maximum } \\
\text { imprisonment } \\
\text { for secondary } \\
\text { insiders }\end{array}$ \\
\hline
\end{tabular}




\begin{tabular}{|c|c|c|c|c|c|c|}
\hline Spain & ComisiónNacional Mercado de Valores (CNMV) & $\begin{array}{l}\text { Securities Market Act (Ley } \\
\text { del Mercado de Valores) }\end{array}$ & 1988 & $?$ & $?$ & $\begin{array}{l}\text { An insider is } \\
\text { anyone who } \\
\text { possesses } \\
\text { inside } \\
\text { information }\end{array}$ \\
\hline $\begin{array}{l}\text { South } \\
\text { Korea }\end{array}$ & The Financial Supervisory Commission & $\begin{array}{l}\text { Securities and Exchange } \\
\text { Act }\end{array}$ & 1962 & $\begin{array}{l}3 \text { times illegal } \\
\text { proceeds }\end{array}$ & 20 years & $\begin{array}{l}18 \\
\text { amendments }\end{array}$ \\
\hline
\end{tabular}

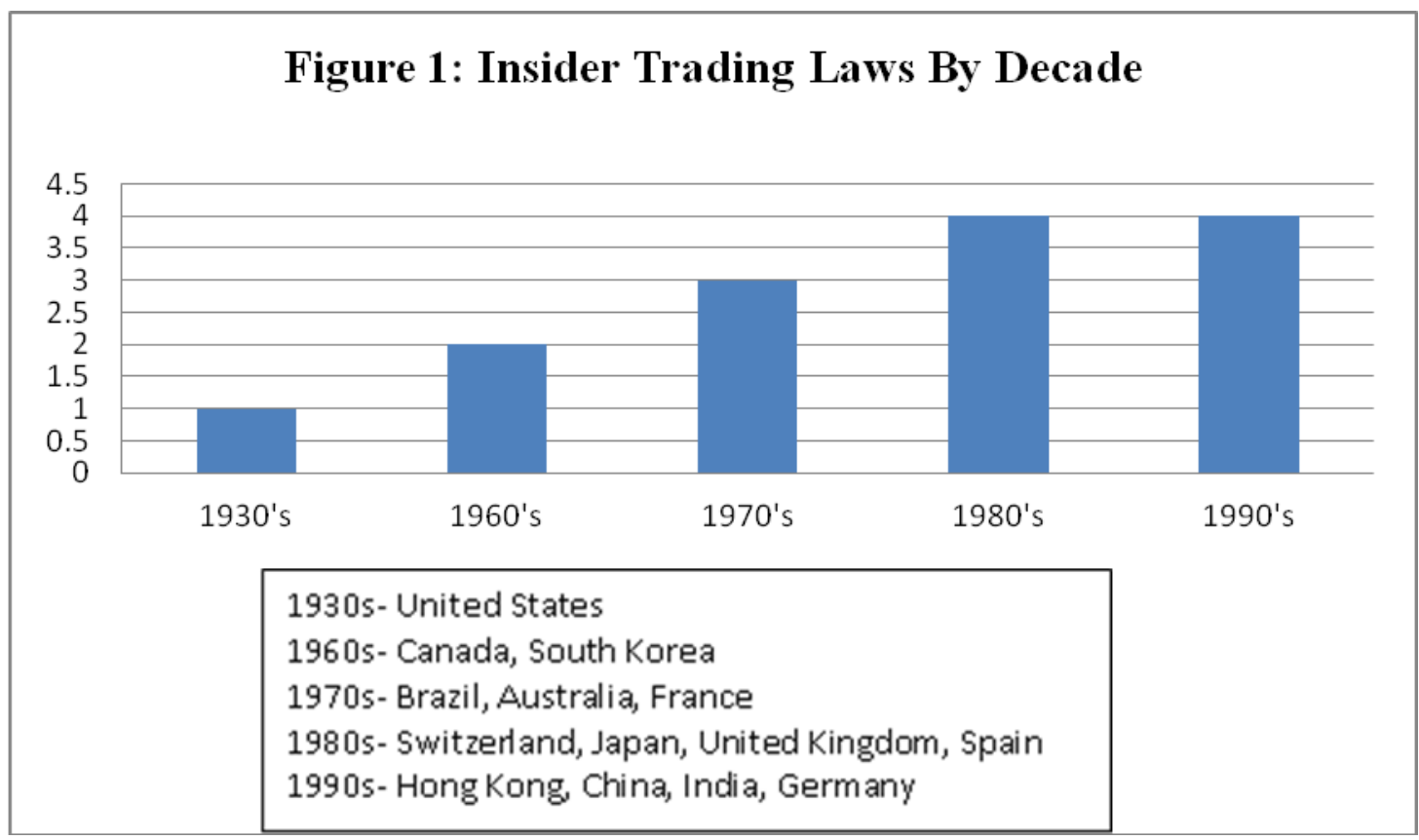

The first step for a country to regulate insider trading is developing federal laws and regulations. The next step is creating a federal organization to enforce the laws and combat against the crime. The study finds that thirteen of the fourteen countries have an integrated federal organization. The one country that does not have federal regulation is Canada. The Canadian regulatory structure is unique because the regulation duties are delegated to individual provinces, and each province creates and manages its own regulations. However, Canada is currently at its infant stage of developing a federal organization to regulate the securities market.

When a country implements a law then there is generally a penalties section within the law that specifies fines and prison time for violators of the law. The study finds that eleven countries have specific fees and fines against insider trading and the other three countries have inconclusive data (Germany, Switzerland, and Spain). Fines and fees range from the lowest with JPY3 million in Japan to EUR 100 million in France and an unlimited amount in the United Kingdom. The penalties section also indicates a maximum prison time for insider trading. In terms of prison time, the study finds that thirteen countries implement a maximum prison time. This study was unable to provide conclusive findings on maximum prison time for Spain. The maximum prison time ranges between two years in France to 
twenty years in United States and South Korea. Five countries have a maximum prison time of ten years: Hong Kong, Canada, Australia, India, and China. The presence of strict fines and penalties indicate that regulators are serious about cracking down on illegal insider trading. Figure 2 compares maximum prison time by country.

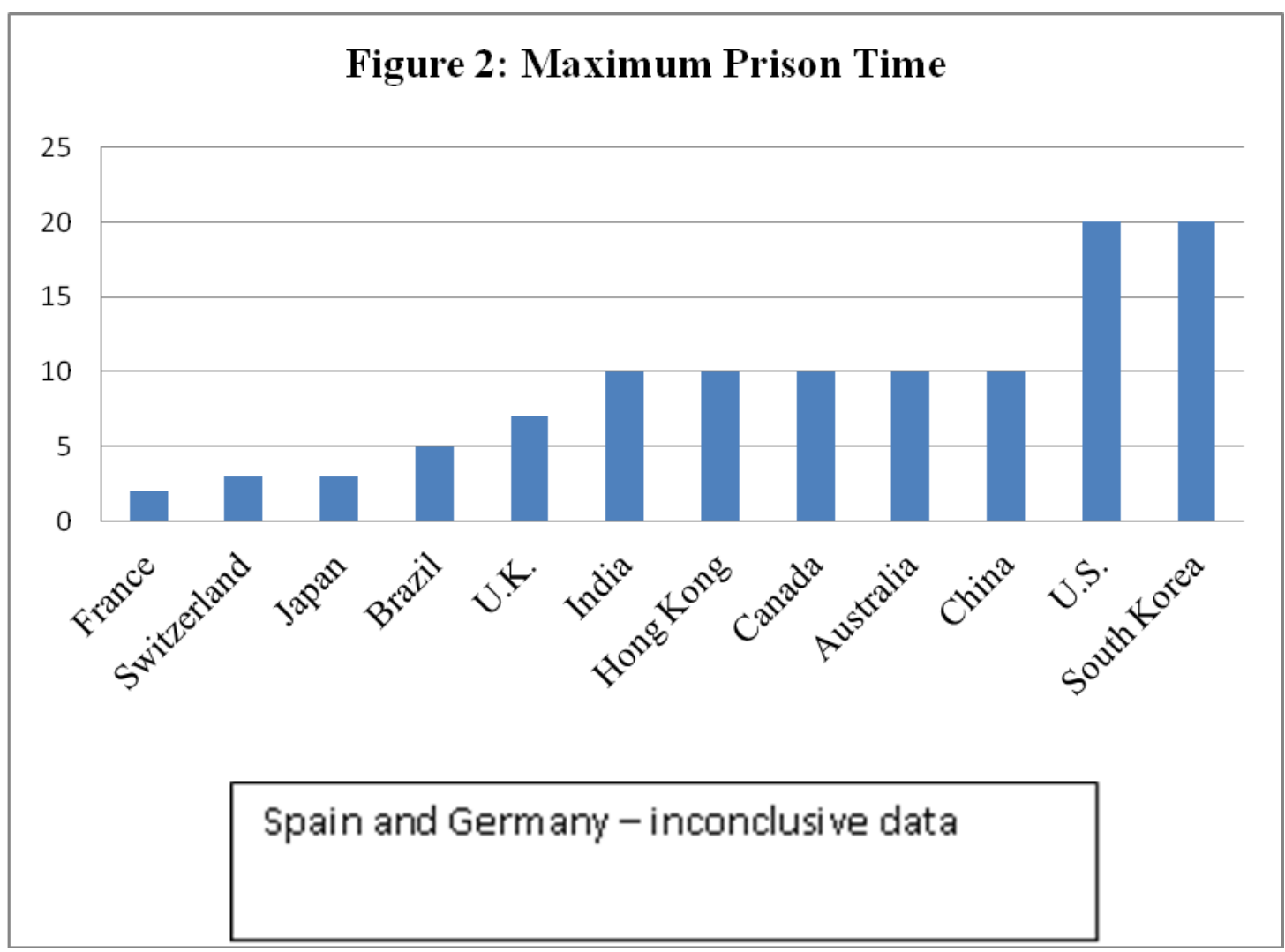

"Insider" and "insider trading" are broadly defined by all fourteen countries. These countries generally agree that the basic definition of an insider includes a director, officer, employee, family member, outsider, tipper, agent, and broker. Despite the consistency of the basic definition of an insider, all fourteen countries also include additional provisions to the definition of an insider. For example, a corporation is an insider in Canada, a trustee is an insider in Hong Kong, congressmen are not considered insiders in the United States, and when an executive quits then he/she is not considered an insider in China. Additionally, all fourteen countries define "insider trading" broadly as well. Each considers insider trading as any persons with non-public information that directly or indirectly benefit from buying or selling any type of securities. There is a consistent viewpoint among the countries that they do not want anyone to improperly benefit from non-public information. Table 3 summarizes how each country defines an insider and insider trading. 
Table 3

\begin{tabular}{|c|c|}
\hline \multicolumn{2}{|c|}{ Who is an Insider Trader? } \\
\hline Countries & Key points \\
\hline United States & Congress does not meet the definition of insider \\
\hline China & When an executive quits they are not considered an insider \\
\hline Japan & $\begin{array}{l}\text { Information must be reported by at least one news outlet to } \\
\text { trade on }\end{array}$ \\
\hline United Kingdom & Any person who has inside information \\
\hline France & Distinguishes between primary and secondary \\
\hline Hong Kong & Include provision about trustee \\
\hline India & Family members must disclose trading \\
\hline Canada & Include the corporation \\
\hline Brazil & Include "standard of loyalty" \\
\hline Australia & No key points \\
\hline Germany & Employees must disclose trades to company \\
\hline Switzerland & Distinguishes between primary and secondary \\
\hline Spain & Anyone with inside information \\
\hline South Korea & No key points \\
\hline
\end{tabular}

Criminal convictions fluctuated within the six countries for which available data was available. In 2010, Brazil secured its first ever conviction, and Canada secured a second ever conviction. India had zero convictions in its history due to its compounding offense and consent process. The United Kingdom had 4 total criminal convictions in its history. On the other extreme, the United States secured 31 criminal convictions in 2009. 


\section{Conclusion}

This study provides valuable data indicating that there are important differences with respect to insider trading laws among the fourteen countries. First, the fourteen countries consistently define an "insider" and "insider trading." Each country defines both terms loosely and broadly because they do not want persons, entities, or anyone to take advantage of non-public information. Second, the study shows that countries are taking insider trading seriously. They are implementing laws and regulations to deter illegal insider trading.

The study also provides important data to suggest that there are some differences with insider trading laws and enforcement activities among the fourteen countries. First, there are inconsistent fines and penalties among the countries, which vary from country to country. There is no apparent correlation between developed and emerging markets. Second, despite limited data, the study indicates that countries as a whole are not effectively enforcing insider trading laws. This finding may be the result of a lack of awareness and education and the lack of resources to combat illegal insider trading.

Recognizing that insider trading occurs, prudent investors must have strategies and mechanisms to protect against insider trading. For example, investors can protect themselves by having a diversified portfolio, hedging market risk, conducting quality analysis, and trusting research. These strategies are necessary because illegal insider trading will continue to be a problem that threatens the integrity of the global market.

This research suggests that global markets face many of the same problems that accounting standards and auditing standards face. Just as efforts across national boundaries have been made to harmonize accounting and auditing standards, similar efforts to harmonize the handling of insider trading issues will benefit traders and stock markets.

\section{References}

Astarita, Mark J., "Introduction to Insider Trading: The Legal Versus the Illegal," SEC law.com, 2010. http://www.seclaw.com/docs/insidertrading033104.htm (20 November 2011).

Betzer, André, and Theissen, Erik, "Insider Trading and Corporate Governance: The Case of Germany," Center for Financial Research, March 2007. http://www.cfr-cologne.de/download/workingpaper/cfr-07-07.pdf (20 November, 2011).

Bris, Arturo, “Do Insider Trading Laws Work?” February, 2005. http://www.arturobris.com/index_files/it.pdf (20 November, 2011).

Brody, Steven, "Criminal Insider Trading: Prosecution, Legislation, and Justification," The $\begin{array}{lllll}\text { Selected } \text { Works Steven } & \text { Brody, }\end{array}$ http://works.bepress.com/cgi/viewcontent.cgi?article=1000\&context=steven_brody

November, 2011).

Canadian Securities $\quad$ Administration, "Overview," 2009. http://www.securities-administrators.ca/aboutcsa.aspx? $\mathrm{id}=45 \&$ linkidentifier=id\&itemid=45 (20 November, 2011). 


\section{Mll Macrothink}

International Journal of Accounting and Financial Reporting ISSN 2162-3082 2013, Vol. 3, No. 1

Canadian Securities Transition Office, Main Page, 2011. http://csto-btcvm.ca/home.aspx (20 November, 2011).

Canadian Securities Administrators, 2010 Enforcement Report, 2011.http://www.securities-administrators.ca/uploadedFiles/General/pdfs/CSA2010Enforcem entReportEng.pdf (20 November, 2011).

Carvalhosa, Modesto, and Nelson Eizirik, "Disclosure and Insider Trading Regulation: Recent Developments in Brazilian Law," Journal of Comparative Corporate Law and Securities Regulation 4 , 1982.http://www.law.upenn.edu/journals/jil/articles/volume4/issue4/CarvalhosaEizirik4J.Co mp.Corp.L.\&Sec.Reg.395\%281982\%29.pdf (20 November, 2011).

Commonwealth Consolidated Acts, Corporations Act 2001 . http://www.austlii.edu.au/au/legis/cth/consol_act/ca2001172/ (20 November 2011).

Del Brio, Esther, Alberto Miguel, and Javier Perote, "An Investigation of Insider Trading Profits in the Spanish Stock Market", The Quarterly Review of Economics and Finance 42, 2002.http://diarium.usal.es/edelbrio/files/2011/02/qref.pdf (20 November, 2011).

De Medeiros, Otavio, "Insider Trading in the Brazilian Stock Market" August 18, 2009.http://papers.ssrn.com/sol3/papers.cfm?abstract_id=1457444 (20 November, 2011).

De Montricher, Nicole, "Changes in the Policy Prohibiting Insider Trading in France," May 2003. www.sog-rc27.org/Paper/DC/Montricher.doc (28 November, 2011).

Department of Justice, Canada, Canada Business Corporations Act,(R.S.C., 1985, c. C-44), Amended October 17, 2011. http://laws-lois.justice.gc.ca/eng/acts/C-44/ (20 November, 2011).

Department of Justice, Canada, Criminal Code, (R.S.C., 1985, c. C-46), Amended August 15, 2011.

http://www.canlii.org/en/ca/laws/stat/rsc-1985-c-c-46/88186/rsc-1985-c-c-46.html\#history (20 November, 2011).

"Elements of Effective Insider Trading Laws ." FMA International, 2008. Web. http://fma2.org/Texas/CompPapers/BlindPapers/Elements_IT.pdf (6 Jun 2012).

Federal Authorities of the Swiss Confederation, Swiss Criminal Code SR 311.0, Art.161.http://www.admin.ch/ch/e/rs/311_0/a161.html (20 November, 2011).

Financial Services Authority, "Enforcing the Code of Market Conduct," 2011. http://www.fsa.gov.uk/pages/doing/regulated/law/focus/conduct.shtml (20 November 2011).

Financial Services Authority, "Why Market Abuse Could Cost You Money,” 2008.

http://www.fsa.gov.uk/pages/doing/regulated/law/focus/conduct.shtml (20 November 2011).

Gide Loyrette Nouel, "The Brief: Financial Services - France", p. 2, March 2011. http://www.gide.com/front/files/GLN_nwsl_France_FinancialServices_EN_mar2011.pdf (28 


\section{NI Macrothink}

International Journal of Accounting and Financial Reporting

ISSN 2162-3082 2013, Vol. 3, No. 1

November, 2011).

Greenwood, John, "Grmovsek Gets 39 Months for Insider Trading," Canada.com, January 7, 2010.http://www.canada.com/business/Grmovsek+gets+months+insider+trading/2415865/sto ry.html (20 November, 2011).

House of Representatives Standing Committee on Legal and Constitutional Affairs, "Mergers, Takeovers and Monopolies: Profiting from Competition?" May, 1989. http://www.aph.gov.au/house/committee/reports/1989/1989_PP141.pdf (20 November, 2011).

Huang, Hui, "The Regulation of Insider Trading in China: A Critical Review and Proposals for Reform," Australian Journal of Corporate Law, Vol. 17, pp. 281-322, 2005. http://ssrn.com/abstract=753745 (20 November 2011).

Hong Kong Special Administrative Region, Securities and Futures Ordinance, Part 1, 2002. http://www.legco.gov.hk/yr01-02/english/ord/ord005-02-e.pdf (20 November, 2011).

Krey, Michael, "Insider Trading Cases Big In Scope, Not Number, In 2009: Report," Investors.com,

2010. http://blogs.investors.com/click/index.php/home/60-tech/1160-insider-trading-cases-big-in-sc ope-not-number-in-2009-report (20 November 2011).

Lawyers and Legal Services Australia, "Recent Insider Trading Convictions In Australia," March

31 ,

2011. http://www.legallawyers.com.au/company-law/recent-insider-trading-convictions-in-australia I (20 November, 2011).

Lee, Charles. "S Korea's energy diplomacy tainted by insider-trading scandal." Platts, 26Jan2012. Web.

http://www.platts.com/RSSFeedDetailedNews/RSSFeed/Oil/7090551 (6 Jun 2012).

"List of stock exchanges." Wikipedia, the free encyclopedia. Wikipedia, 12 June 2012. Web. http://en.wikipedia.org/wiki/List_of_stock_exchanges (12 June 2012).

Luna, Denise, and ElzioBarreto, “Credit Suisse Settles Brazil Insider Trading Case," Reuters, October

2009.http://www.reuters.com/article/2009/10/20/creditsuisse-embraer-idUSN2044480220091 $\underline{020}$ (20 November, 2011).

Mao, Debra, "Chaoda's Chairman and CFO, Fidelity Manager Accused of Insider Trading," Bloomberg, September 28, 2011.http://www.bloomberg.com/news/2011-09-28/chaoda-s-chairman-and-cfo-fidelity-mana ger-accused-of-insider-trading.html\# (20 November, 2011).

Masters, Brooke, "FSA Wants Tougher Insider Trade Penalties," Financial Times, May 15, 2011.

http://www.ft.com/intl/cms/s/0/453db2ba-7f31-11e0-b239-00144feabdc0.html\#axzz1eJvFw5 Uv (20 November, 2011). 


\section{Macrothink}

International Journal of Accounting and Financial Reporting ISSN 2162-3082 2013, Vol. 3, No. 1

Meany, Patrick, “Japan Steps Up Insider Trading Enforcement Efforts," Deloitte Tohmatsu FAS,

2010.http://www.tohmatsu.com/assets/Dcom-Japan/Local\%20Assets/Documents/service/fas/j p_s_fas_fds_en03_010610.pdf (20 November 2011).

Mehta, Mona, "How Rampant is Insider Trading on Dalal Street?" Banking, Finance, Markets, March 2011. http://www.businessandeconomy.org/bfm/20110301/pdf/bfm.pdf (20 November, 2011).

Ministry of Legislation, "Securities And Exchange Act (Republic of Korea)." Unpan1.un.org. Ministry of Legislation, 08May2003. Web.

http://unpan1.un.org/intradoc/groups/public/documents/apcity/unpan011491.pdf $\quad$ (6 Jun 2012).

Monetary and Financial Code, Article L465-1, July 27, 2005. http://195.83.177.9/code/liste.phtml?lang=uk\&c=25\&r=906 (28 November, 2011).

Newkirk, Thomas C., and Melissa A. Robertson, "Insider Trading - A US Perspective," Speech by SEC Staff at $16^{\text {th }}$ International Symposium on Economic Crime, 1998.

http://www.sec.gov/news/speech/speecharchive/1998/spch221.htm

Overland, Julie, "Nibbling at the Edges or Fiddling While Rome Burns? The Past, Present, and Future Regulation of Insider Trading," 2011.http://www.clta.edu.au/professional/papers/conference2011/Article\%20-\%20CLTA\%20 2011\%20Past\%20Present\%20and\%20Future\%20Regulation\%20Insider\%20Trading\%20Fina 1.pdf (20 November, 2011).

PerthNow, "WA Men Charged With Insider Trading," April 1, 2011. http://www.perthnow.com.au/business/wa-men-charged-with-insider-trading/story-e6frg2rl-1 $\underline{226032172476}$ (20 November, 2011).

Pulliam, Susan, and Chad Bray, "Trader Draws Record Sentence," The Wall Street Journal, October 14 , 2011. http://online.wsj.com/article/SB10001424052970203914304576627191081876286.html (20 November 2011).

Ramseyer, J. Mark, "Insider Trading Regulation in Japan," Harvard Law, Economics and Business Discussion Paper No. 705, August 23, 2011. http://ssrn.com/abstract=1915284 (20 November 2011).

Rechtsanwälte, Thouvenin, "Switzerland: Insider Trading," IFLR, March 1, 2007. http://www.iflr.com/Article/1977321/Insider-trading.html (20 November, 2011).

Rodrigues, Vivianne, "Brazil Regulator Wins First Insider Trading Case," FT Tilt.com, February

18 2011.http://tilt.ft.com/\#!posts/2011-02/13691/brazil-regulator-wins-first-insider-trading-case (20 November, 2011). 
Sainsbury, Michael, "Insider Trading Rife in Australia," The Australian, February 20, 2008.http://www.news.com.au/money/investing/insider-trading-rife-in-australia/story-e6frfm dr-1111115597296 (20 November, 2011).

Sasanow, Richard, "The Globalization of Insider Trading," A Plus, April 2008.http://app1.hkicpa.org.hk/APLUS/0804/p16-19.pdf (20 November, 2011).

Savada, Andrea, and William Shaw. "South Korea - Financing Development." South Korea: A Country Study. Countrystudies.us, 1990. Web.

http://countrystudies.us/south-korea/49.htm (6 Jun 2012).

Securities Exchange Act of 1934, Section 21A, reprinted by the University Of Cincinnati College Of Law. http://taft.law.uc.edu/CCL/34Act/sec21A.html (20 November, 2011).

Securities and Exchange Board of India Act, No. 15 of 1992.http://www.sebi.gov.in/acts/act15ac.html (20 November, 2011).

Securities and Exchange Board of India, "Frequently Asked Questions," April 20, 2007. http://www.sebi.gov.in/faq/consentord-faq.pdf (20 November, 2011).

Securities and Exchange Board of India, (Prohibition of Insider Trading) (Amendment) Regulations, 2008.http://www.sebi.gov.in/acts/prohibition.pdf (20 November, 2011).

Securities Trading Act (Gesetzüber den Wertpapierhandel/Wertpapierhandelsgesetz - WpHG), September 9, 1998.http://www.iuscomp.org/gla/statutes/WpHG.htm (20 November, 2011).

Shen, Han, "A Comparative Study of Insider Trading Regulation Enforcement In the U.S. and China," Journal of Business \& Securities Law, Vol. 9, No. 1, Fall 2008. http://ssrn.com/abstract=964548 (20 November, 2011).

SIX Swiss Exchange, "Supervisory Authorities and Penalties," October 5, 2009. http://www.six-swiss-exchange.com/download/trading/training/education/material/2_4_super vis_authorit_and_penalt_en.pdf (20 November, 2011).

Steward, Mark, Speech at Hong Kong Securities Institute SFC Executive Directors Series, September 3, 2009. http://www.sfc.hk/sfc/doc/EN/speeches/speeches/09/Mark_20090903.pdf (20 November, 2011).

Sutton, John, "Insider Trading Cases in Australia," Armstrong Legal, 2010.http://www.armstronglegal.com.au/web/page/insider trading_cases (20 November, 2011).

The Economist, "Tipping the Scales: The Fight Against Crooked Trading Gathers Pace".

October 15, 2011.http://www.economist.com/node/21532280 (20 November 2011).

Welch, Jane, et al., "Comparative Implementation of EU Directives (I) - Insider Dealing and Market Abuse," British Institute of International and Comparative Law, December 2005.http://www.cityoflondon.gov.uk/NR/rdonlyres/3950D4A4-5792-412C-BA89-1B308271 01C7/0/BC_RS_eudirectives_1205_FR.pdf (20 November, 2011). 


\section{Macrothink
Instrtute}

Xydias, Alexis, and James Lumley, "FSA Struggles With Insider Trading That Doesn't Happen In U.K.," Bloomberg, June 11, 2007. http://www.bloomberg.com/apps/news?pid=newsarchive\&sid=a0Le7f.KNDos\&refer=home (20 November, 2011) 